NBER WORKING PAPER SERIES

\title{
DO FIRMS IN COUNTRIES WITH POOR PROTECTION OF INVESTOR RIGHTS HOLD MORE CASH?
}

\author{
Lee Pinkowitz \\ Rene M. Stulz \\ Rohan Williamson \\ Working Paper 10188 \\ http://www.nber.org/papers/w10188 \\ NATIONAL BUREAU OF ECONOMIC RESEARCH \\ 1050 Massachusetts Avenue \\ Cambridge, MA 02138 \\ December 2003
}

René Stulz is grateful for the hospitality of the Kellogg School at Northwestern University and of the Stigler Center at the University of Chicago, where some of this research was conducted. We thank Kathryn-Ann Bloomfield, Michael Chiang, Mark Ervin, Jennifer Rooke, and especially Aaron Kravitz, for their help with the data collection. We are grateful to Ole-Kristian Hope, Jan Mahrt-Smith, and seminar participants at the University of Toronto for useful comments. The views expressed herein are those of the authors and not necessarily those of the National Bureau of Economic Research.

(C2003 by Lee Pinkowitz, Rene M. Stulz, and Rohan Williamson. All rights reserved. Short sections of text, not to exceed two paragraphs, may be quoted without explicit permission provided that full credit, including (C) notice, is given to the source. 
Do Firms in Countries with Poor Protection of Investor Rights Hold More Cash?

Lee Pinkowitz, Rene M. Stulz, and Rohan Williamson

NBER Working Paper No. 10188

December 2003

JEL No. G15, G31, G32

\section{$\underline{\text { ABSTRACT }}$}

Managers make different decisions in countries with poor protection of investor rights and poor financial development. One possible explanation is that shareholder-wealth maximizing managers face different tradeoffs in such countries (the tradeoff theory). Alternatively, firms in such countries are less likely to be managed for the benefit of shareholders because the poor protection of investor rights makes it easier for management and controlling shareholders to appropriate corporate resources for their own benefit (the agency costs theory). Holdings of liquid assets by firms across countries are consistent with Keynes' transaction and precautionary demand for money theories. Firms in countries with greater GDP per capita hold more cash as predicted. Controlling for economic development, firms in countries with more risk and with poor protection of investor rights hold more cash. The tradeoff theory and the agency costs theory can both explain holdings of liquid assets across countries. However, the fact that a dollar of cash is worth less than $\$ 0.65$ to the minority shareholders of firms in such countries but worth approximately $\$ 1$ in countries with good protection of investor rights and high financial development is only consistent with the agency costs theory.

Lee Pinkowitz Georgetown University pinkowitz@msb.edu
Rene M. Stulz

Fisher College of Business

Ohio State University

806A Fisher Hall

2100 Neil Avenue

Columbus, OH 43210-1144

and NBER

stulz@cob.osu.edu
Rohan Williamson

Georgetown University 


\section{Introduction}

Recent work shows that countries where institutions that protect investor rights are weak perform poorly along a number of dimensions. In particular, these countries have lower growth, less well-developed financial markets, and more macroeconomic volatility. ${ }^{1}$ To measure the quality of institutions, authors have used, for instance, indices of the risk of expropriation, the level of corruption, and the rule of law. Since poor institutions could result from poor economic performance rather than cause it, authors have also used the origin of a country's legal system (La Porta, Lopez-de-Silanes, Shleifer, and Vishny, LLSV1, 1998), the nature of the activities of its colonizers (Acemoglu, Johnson, and Robinson, 2001), and its culture (Stulz and Williamson, 2003) as instruments for the quality of institutions.

For the quality of institutions to matter for economic performance, it has to affect the actions of firms and individuals. Recent papers examine how dividend, investment, asset composition, and capital structure policies are related to the quality of institutions. ${ }^{2}$ In this paper, we focus more directly on why firm policies depend on the quality of institutions. The quality of institutions can affect firm policies for two different reasons. First, a country's protection of investor rights may influence the relative prices or tradeoffs managers face when making decisions, so that actions that maximize shareholder wealth in countries where investor rights are well protected may not be optimal in other countries. We call this explanation the tradeoff theory. Second, poor protection of investor rights makes it more difficult for non-controlling investors to receive a return from their investment because agency conflicts are harder to govern. We call this explanation the agency costs theory. With this theory, managers make different decisions in countries where investor rights are poorly protected because they face fewer constraints in

\footnotetext{
${ }^{1}$ See Levine (1997), La Porta, Lopez-de-Silanes, Shleifer, and Vishny (2000), and Easterly (2001) for reviews of the evidence.

${ }^{2}$ See, for instance, La Porta, Lopez-de-Silanes, Shleifer, and Vishny (2000) for dividends, Claessens and Laeven (2003) for the allocation of assets within the firm, Love (2000) for investment, Demirgüc-Kunt and Maksimovic (1998) for external finance, and Booth, Aivazian, Demirgüc-Kunt, and Maksimovic (2001) for capital structure.
} 
pursuing policies that do not maximize shareholder wealth. In this paper, we study the relative importance of the tradeoff and agency costs theories for why firms act differently in countries with poor protection of investor rights.

Using a sample that spans 35 countries and twelve years, we find that firms in countries with poorer institutions hold more liquid assets (which we also call cash) than they would if they were located in the U.S. The effect is economically important. For instance, in a cross-country regression that controls for GDP per capita, financial development, stock return volatility, and inflation, a firm in a country with the worst institutions has from $5 \%$ to $25 \%$ more liquid asset holdings in proportion to total assets than a U.S. firm depending on the index of institution quality used.

We focus our analysis on cash holdings by firms because, since Keynes (1934), there has been little controversy in the literature about the determinants of cash holdings when agency costs are unimportant. Keynes (1934) explains that firms can hold cash to reduce transaction costs (the transaction motive) and to provide a buffer to absorb adverse shocks (the precautionary motive). The transaction motive predicts that cash holdings are positively related to economic development. With the transaction motive, firms hold cash to economize on the costs of transacting. The transaction motive is a "shoe leather" theory of money demand: it is cheaper to hold cash than to send somebody to the bank. As a result, cash holdings increase with the cost of labor. The tradeoff theory therefore predicts a positive relation between cash holdings and economic development. We find that inferences about the relation between cash holdings and investor protection depend crucially on controlling for economic development. Without controlling for economic development, investor protection proxies for economic development in regressions and there is a negative relation between cash holdings and investor protection.

Opler et al. (1999) provide evidence on the importance of the precautionary motive for cash holdings in the U.S. The precautionary motive could explain why firms in countries with poorer 
institutions hold more liquid assets. First, Acemoglu, Johnson, Robinson, and Thaicharoen (2003) show that countries with poorer institutions are less stable. In such countries, firms are more likely to face disruptions that require the use of liquid assets. Some of these business interruptions might result from breakdowns in law and order, others might be due to political interferences, and some might just be attempts to shake down firms. Regardless of the source of these business interruptions, firms have to hold more liquid assets than in more stable countries with better institutions. Second, countries with poor institutions are less financially developed. Substitutes for liquid asset holdings are more costly in such countries, or may not even be available. For instance, firms that have easy access to external capital markets should not have to hold as much of a buffer stock of liquid assets, but access to external capital markets is limited and expensive in countries with low financial development. Therefore, the tradeoff theory predicts that firms hold more cash in countries with poorer institutions keeping economic development constant and that firms hold less cash in countries with lower economic development keeping the quality of institutions constant.

In the U.S., an explanation advanced for high cash holdings, the free cash flow explanation of Jensen (1986) is that management would rather hold cash than pay dividends to shareholders. Dittmar, Mahrt-Smith, and Servaes (DMS, 2003) test the free cash flow hypothesis across a number of countries for two years and show that liquid asset holdings are higher in countries with a lower value of the anti-director rights index constructed by Lopez-de-Silanes, La Porta, Shleifer, and Vishny (LLSV1, 1998). The anti-director rights index measures the legal rights of minority shareholders and has a higher value if laws protect minority shareholders better. They interpret this result as supportive of the free cash flow explanation for high cash holdings outside the U.S. Assuredly, there are firms where their explanation applies, but it cannot be the whole story for three reasons. First, firms in countries with poor institutions hold more cash with the tradeoff model, so that greater cash holdings in these countries can be explained without recourse to 
agency costs. Second, their specifications do not control for differences in economic development across countries. In contrast to other measures of investor protection, the anti-director rights index is negatively correlated with economic development in our sample so that the tradeoff theory predicts that cash holdings are negatively correlated with the anti-director rights index when one does not control for economic development. Hence, the DMS result could be fully consistent with the tradeoff model. Third, since non-U.S. firms tend to be controlled by large shareholders, managers in these firms can be monitored closely by the large shareholders, so that the large shareholders must want their firms to have high holdings of liquid assets. The large shareholders would rather keep cash within the firm than give it to minority shareholders. However, they can also siphon cash from the firm in the form of private benefits, a practice called tunneling (see Johnson, La Porta, Lopez-de-Silanes, Shleifer, 2000). If the controlling shareholder can easily extract private benefits from control, we would not expect the free cash flow agency theory to apply.

The existing literature typically models private benefits in one-period models (see, for instance, La Porta, Lopez-de-Silanes, Shleifer, and Vishny (LLSV2), 2002, and Shleifer and Wolfenzon, 2003). Such an approach assumes that extraction of private benefits takes place with equal intensity in every period. Though this simplification is often useful, it makes it impossible to analyze the timing of tunneling. Through aggressive extraction of private benefits now, the controlling shareholder may reduce the value of future private benefits. Consequently, the controlling shareholder may choose to refrain from consuming private benefits when he benefits more from investing resources in the firm to increase his future private benefits. Yet, if the controlling shareholder has two ways of investing firm funds that have similar expected gross returns, he will prefer the investment that makes it possible for him to eventually consume more private benefits, so that investments that make extraction of private benefits easier will be advantaged. Investment in liquid assets is preferred by controlling shareholders because, as Myers 
and Rajan (1998) point out, liquid assets can more easily be used than fixed assets to enrich the large shareholder at the expense of other investors in the corporation. Johnson, La Porta, Lopezde-Silanes, and Shleifer (2000) provide one example of tunneling in Belgium where the controlling shareholder simply took a substantial sum from the firm's accounts, i.e., the firm's liquid assets. The court did not force him to give the money back after he was sued by the minority shareholders. Fixed assets can be traced - a plant cannot disappear, but cash can. We construct a model where we show that, when the quality of institutions is low, the controlling shareholder will choose to hold more assets that can be more easily expropriated.

The tradeoff theory and the agency costs theory both can predict that firms hold more cash in countries with poor institutions. We devise a straightforward test to discriminate between these hypotheses. Using a modification of the valuation model put forward in Fama and French (1998), we estimate how much cash holdings contribute to firm value in countries with institutional quality above and below the median. If firms in countries with poorer institutions hold more liquid assets because they can more easily be expropriated by controlling shareholders, it should be that liquid asset holdings do not contribute as much to firm value as they do in countries with better institutions. In other words, in a country where each dollar of cash belongs to shareholders regardless of whether they are controlling shareholders or not, a dollar of cash should contribute approximately a dollar of firm value. However, if part of a dollar of cash will eventually be expropriated by controlling shareholders, a dollar of cash should be worth less than a dollar to minority shareholders. Strikingly, while a dollar of cash is worth roughly a dollar of firm value in the U.S., in countries with poor institutions, a dollar of cash is consistently estimated to be worth less than 65 cents. We therefore conclude that the larger holdings of liquid assets in countries with poorer institutions are not the result of decisions made by controlling shareholders to maximize firm value. 
The paper proceeds as follows. In Section 2, we model the cash holding decision for the controlling shareholder and derive our predictions that liquid asset holdings are inversely related to the quality of institutions and to the level of financial development of a country, but positively related to the country's level of economic development. Additionally, our model suggests that the value of cash holdings to minority shareholders in a country is inversely related to that country's degree of investor protection. In Section 3, we discuss how we construct our sample and measure liquid asset holdings compared to liquid asset holdings of firms in the U.S. In Section 4, we show that liquid asset holdings fall as institutions become better. In Section 5, we find that the value of liquid assets for minority shareholders is positively related to the quality of institutions. We conclude in Section 6.

\section{Liquid asset holdings and the quality of institutions}

In this section, we derive predictions for cash holdings when controlling shareholders or managers can divert corporate resources for their private benefit. The predictions of the tradeoff theory are a special case of this model. Since in the international context, large firms are typically controlled by large shareholders who can impose their will on management (see La Porta, Lopezde-Silanes, and Shleifer, 1999), we call the agent who controls the firm the controlling shareholder for simplicity. The model draws on the insight of Myers and Rajan (1998) that it is easier for managers and controlling shareholders to extract private benefits from cash than from plant and equipment. The Myers and Rajan (1998) model builds on Hart and Moore (1994), where firms cannot raise capital against all of a project's cash flows because they cannot enter enforceable contracts to pledge all the cash flows to capital providers. We do not use the Hart and Moore (1994) model here, but as shown by Almeida, Campello, and Weisbach (2003), that model provides a motivation for firms to hold liquid assets that is related to Keynes' precautionary demand for money. Rather, we follow the approach of LLSV2 to model private benefits. With 
that approach, the large shareholder can extract private benefits, but extraction of private benefits imposes a deadweight cost on the firm. This cost is due to the fact that the extraction of private benefits has to be disguised, but more so in countries with better institutions.

In this model, the firm's cash flow $\mathrm{C}$ depends on physical capital $\mathrm{K}$ and liquid assets $\mathrm{L}$. Liquid assets are required for production. This captures the transaction and precautionary motives for holding cash. The production function is a Cobb-Douglas production function:

$$
C=Q K^{\beta} L^{1-\beta}
$$

We are only concerned about how firms allocate capital between $\mathrm{K}$ and L. To examine this issue, we assume that the firm has a given amount of capital, A, cannot raise additional capital, and does not have other productive uses for capital. With this setup, the opportunity cost of capital is equal to zero once raised by the firm. This setup makes it possible to distinguish sharply between financing issues and asset allocation issues. As emphasized by Claessens and Laeven (2003), the literature has focused much more on financing issues than asset allocation issues. Our paper focuses on the latter issues.

The controlling shareholder has cash flow rights $\alpha$, so that he receives a fraction $\alpha$ of the distributions made to shareholders. Let $\mathrm{f}$ be the fraction of cash flow appropriated by the controlling shareholder at the expense of the other shareholders. The deadweight cost to the firm of having cash flow diverted by the controlling shareholder is a quadratic function of the amount diverted, $0.5 \mathrm{~b}(\mathrm{fC})^{2}$. The parameter $\mathrm{b}$ measures the quality of institutions. A higher value for $\mathrm{b}$ means that cash flow diversion is more expensive. The cash flow received by the controlling shareholder is $\left(f+\alpha\left[1-f-0.5 b f^{2}\right]\right) C$ and the minority shareholders receive $(1-\alpha)(1-f-$ $\left.0.5 \mathrm{bf}^{2}\right) \mathrm{C}$. 
In LLSV2, the cash flow is a liquidating cash flow. We assume that instead the firm has assets at date 1 in addition to its operating cash flow. The controlling shareholder can divert some of these assets for his own use as the firm is liquidated. A natural extension of this model would be to have more than one period, so that the controlling shareholder could decide each period how much he expropriates from current cash flow and decide how much of the liquid assets to expropriate. To emphasize the distinction between cash and other assets, we assume that the controlling shareholder can divert liquid assets but not physical capital. When the firm is liquidated, the physical capital is sold for $\mathrm{K}$ and the controlling shareholder receives a fraction $\alpha$ of $\mathrm{K}$. To keep the notation simple, we assume that the cost of diverting liquid assets is the same as the cost of diverting cash flow. The controlling shareholder diverts a fraction $\gamma$ of the liquid assets at a cost to the firm of $0.5 b \gamma^{2} \mathrm{~L}$ paid out of the firm's liquid assets. Consequently, the controlling shareholder receives $\left(\gamma+\alpha\left[1-\gamma-0.5 \mathrm{~b} \gamma^{2}\right]\right) \mathrm{L}$ from the firm's liquid assets and the minority shareholders receive $(1-\alpha)\left(1-\gamma-0.5 \mathrm{~b} \gamma^{2}\right) \mathrm{L}$.

With our notation, the proceeds to the large shareholder, $\mathrm{P}$, at date 2 are:

$$
P=\left(f+\alpha-\alpha f-0.5 \alpha b f^{2}\right) C+\left(\gamma+\alpha-\alpha \gamma-0.5 \alpha b \gamma^{2}\right) L+\alpha K
$$

The controlling shareholder chooses $f, \gamma$, and $\mathrm{L}$ to maximize $\mathrm{P}$ subject to the constraints that $\mathrm{f}$ and $\gamma$ cannot be negative and cannot exceed 1 , that $\mathrm{L}$ cannot be negative, and that $\mathrm{K}=\mathrm{A}-\mathrm{L}$. The first-order conditions for an interior solution for $\mathrm{L}$ are: 


$$
\begin{aligned}
& \frac{\partial P}{\partial f}=(1-\alpha-\alpha b f) C=0 \\
& \frac{\partial P}{\partial \gamma}=(1-\alpha-\alpha b \gamma) L=0 \\
& \frac{\partial P}{\partial L}=\left(f+\alpha-\alpha f-0.5 \alpha b f^{2}\right) Q\left[-\beta(A-L)^{\beta-1} L^{1-\beta}+(1-\beta)(A-L)^{\beta} L^{-\beta}\right] \\
& +\left(\gamma+\alpha-\alpha \gamma-0.5 \alpha b \gamma^{2}\right)-\alpha=0
\end{aligned}
$$

Solving for f and $\gamma$ using (3a) and (3b), we obtain:

$$
f=\gamma=\frac{1-\alpha}{\alpha b}
$$

As in LLSV2, the rate of diversion falls as the quality of institutions increases and decreases as ownership increases.

We cannot solve explicitly for L, but we can obtain comparative statics for L. First, we want to know how an increase in the quality of institutions, i.e., a decrease in corruption, affects L:

$$
\begin{aligned}
& \frac{d L}{d b}=\frac{\left[0.5 \alpha(1-\alpha)^{2}+\alpha^{2}\right](1+Y) / b^{2}}{\partial Y / \partial L} \\
& \text { where } Y=Q\left[-\beta(A-L)^{\beta-1} L^{1-\beta}+(1-\beta)(A-L)^{\beta} L^{-\beta}\right]
\end{aligned}
$$

The denominator of equation (5) has the same sign as the second derivative of the large shareholder's proceeds with respect to liquid assets, which is negative because $\mathrm{P}$ is a concave function of L. With our assumptions, it therefore follows that:

Proposition 1: Cash holdings are negatively related to the quality of institutions. 
Note that the derivation of Proposition 1 is based on the positive relation between the extraction of private benefits and the quality of institutions. The introduction provides a second reason for why cash holdings are negatively related to the quality of institutions. That reason is not modeled here. With Keynes' precautionary demand for money, money demand increases with uncertainty and there is more uncertainty in countries where the quality of institutions is lower. Hence, Proposition 1 holds even in the absence of agency costs, so that it cannot be used to distinguish between the tradeoff theory and the agency costs theory.

In this model, there is an advantage to liquid asset holdings for the controlling investor, which is that he gets more out of $\$ 1$ of cash than he gets out of $\$ 1$ of physical capital when the firm liquidates. This tilts the firm's assets towards more cash than in the first best solution. However, as the cost of diverting cash for his personal benefit increases because of better institutions, i.e., as $b$ increases, the large shareholder finds it less advantageous to divert cash and consequently the cash holdings fall.

In the literature on money demand by firms, a higher level of "monetary technology" implies lower holdings of cash (see Mulligan, 1997). By having access to a wide choice of financial instruments and to the ability to trade securities at lower cost, a firm can economize on cash. In our model, we can take into account the level of "monetary technology" available in a country by replacing cash holdings in the production function by $f(L, q)$, where $q$ is a productivity index for cash, so that $f(L, q)$ increases with q. An increase in q means that a smaller amount of cash leads to the same cash flow as before. We equate an increase in $\mathrm{q}$ to an increase in financial development. For simplicity, we assume that $\mathrm{f}(\mathrm{L}, \mathrm{q})=\mathrm{L}+\mathrm{q}$. The derivative of liquid asset holdings with respect to $\mathrm{q}$ is negative:

Proposition 2: Cash holdings are negatively related to financial development. 
There is an extremely large literature on the demand for money. In that literature, cash substitutes for labor, so that when labor becomes more expensive, cash holdings increase. For instance, Mulligan (1997) finds for the U.S. that the elasticity of money demand with respect to a proxy for the cost of labor is about 0.6 . The opportunity cost of labor increases with economic development since human capital increases with economic development. This implies that cash becomes more valuable as economic development increases:

Proposition 3: Liquid asset holdings are positively related to economic development.

Propositions 2 and 3 hold irrespective of whether the actions of firms are explained by the tradeoff theory or the agency costs theory.

Investors assign a value to the cash holdings of the firm and the issues that impact the level of corporate cash holdings should also affect the valuation of the marginal liquid asset held by the firm. Therefore, we also want to know how the value of the firm is related to liquid asset holdings. We normalize values so that they are in current dollars. The value of the firm's shares is:

$$
V=A+C-0.5 b\left(\frac{1-\alpha}{\alpha b}\right)^{2} C-0.5 b\left(\frac{1-\alpha}{\alpha b}\right)^{2} L
$$

With this valuation formula, the value of the firm is equal to the sum of its assets and its cash flows minus a discount for cash flow and a discount for cash. The discount for cash flow and for cash is due to the fact that they are subject to diversion activities from the large shareholder and that these diversion activities have a deadweight cost. The discount is inversely related to the quality of institutions. It follows from this that: 
Proposition 4: When the controlling shareholder makes firm decisions to maximize his welfare, the value of a dollar of liquid assets held by the firm falls for minority shareholders as the quality of institutions falls. Otherwise, there is no discount for cash.

The reason the discount for cash increases as the quality of institutions worsens is that more cash is diverted by the controlling shareholder. With the tradeoff theory, the firm is managed to maximize its value, so that no diversion takes place and there are no discounts. Proposition 4 therefore makes it possible to distinguish between the tradeoff and the agency costs theory.

In formulating the tradeoff theory of cash holdings, we have ignored the role of corruption. If corruption is high, one might be tempted to conclude that firms have to hold cash so that they can "grease the wheels of commerce" to use the felicitous expression of Kaufman and Wei (1999). For instance, in a high corruption environment, firms face the need to pay off functionaries and need to have liquid assets available. This possible explanation for higher cash holdings in countries with poorer institutions implies that cash holdings are efficient. Though cash is used to pay off functionaries, doing so makes the firm more profitable and it is therefore optimal for firms to hold more cash. Consequently, a dollar of cash should be worth at least a dollar to shareholders.

\section{Data}

The firm level data come from Worldscope and span the years 1988-1999. Because financial firms hold liquid assets for different reasons than other firms, we exclude firms in SIC codes starting with 6. The country level data come from various sources and represent measures of institutional quality, financial development, and economic development of the country. We start from the countries used in LLSV1, but our data requirements force us to limit the study to 35 countries from 1988 through 1999. Though much of the existing research 
investigates the relation between firm policies and the quality of institutions for a one-year crosssection, investigating the relation between firm policies and institution quality over multiple years makes it less likely that the estimated relation is spurious.

To examine institutional quality, we use data from LLSV1 that measures corruption, respect for the rule of law, expropriation risk, protection of minority shareholders (the anti-director rights index), and the origin of the legal system. The corruption, rule of law, and expropriation indices are produced by the country-risk rating agency International Country Risk (ICR). Corruption is an assessment of the risk of corruption of high government officials, while rule of law is an assessment of the law and order tradition in a country. Expropriation risk is the threat of outright confiscation or "forced nationalization." All ICR indices used by LLSV1 are averages from 1982 through 1995 and are scaled so that their values go from one through ten, with one representing the worst possible enforcement and ten the highest. The anti-director rights index is built by LLSV1. The index sums up dummy variables that take value one if a right protecting minority shareholders is mandated in a country. There are five such rights, so that the highest value of the index is five.

Though the LLSV1 indicators of the quality of institutions have been widely used in the literature, these indicators are averages measured at one point in time. Over a period of 12 years, the quality of institutions can change across countries and these changes can affect firm policies. We therefore also use indicators of the quality of institutions that change over time. The International Country Risk Guide data on the country's political risk level (ICRGP index) is available monthly for our sample period. The political risk level is made up of twelve components that comprise the overall political risk assessment of a country. We use the index for political risk as well as the components of that index measuring corruption and the rule of law. Our indices are created annually by taking the average of all the months in a given year. Finally, we use an index which measures political constraints to assess the probability of corruption or extreme policy 
change in a country. The PolconV Index is developed in Henisz (2000) and is available annually for our countries. The index is a continuous variable ranging from zero, indicating a dictatorship, to one, indicating democracy, and represents the degree to which checks and balances are present in a country's political system. For our purpose, the variable examines institution quality in the sense that the more centralized the government, the higher the opportunity for corruption (see Shleifer and Vishny, 1993). As with the LLSV1 variables, the ICRGP and PolconV indexes are constructed so that a higher index level corresponds to better institutions. The corruption and rule of law indices from ICRGP are normalized so that they are computed on a scale from 1 to 10 as in LLSV1.

Data on GDP and inflation are taken from the World Bank World Development Indicators (WDI) database. As a proxy for uncertainty at the country level, we use stock market volatility. We expect the precautionary motive to be more important for countries with greater uncertainty. We calculate a measure of overall stock market volatility using the standard deviation of the prior 60 months of returns of the country index. Market index return data come from Datastream.

We also examine several measures of financial development within a country. From the WDI database, we have data on stock market turnover and stock market capitalization. Stock market turnover is the ratio of the total shares traded to the stock market capitalization. It is a proxy for stock market liquidity. Stock market capitalization is normalized by GDP and is a measure of the size of equity markets in an economy. The description and justification of the use of these variables are developed in Beck et al. (1999). The Bank for International Settlements (BIS) Quarterly Review provides total domestic debt outstanding (excluding government) normalized by the country's GDP, which we use as a proxy for the level of development of a country's debt market.

If a firm is controlled by large shareholders, these shareholders may want the firm to hold more liquid assets to reduce the risk of their investment. In other words, the firm may end up 
over-emphasizing the precautionary motive for cash. In our country regressions, we use a measure of ownership concentration by using the closely held shares percentage taken from the Worldscope database. Closely-held shares correspond to shares held by insiders. Insiders are considered to be officers, directors, and their immediate families, shares held in trusts, shares held by another corporation (except shares held in a fiduciary capacity by financial institutions), shares held by pension benefit plans, and shares held by individuals who hold $5 \%$ or more of the outstanding shares. For Japanese firms, closely held shares represent the holdings of the ten largest shareholders. For each country, we use a value-weighted average of inside ownership across firms (see Dalquist, Pinkowitz, Williamson, and Stulz, 2003)).

In an attempt to benchmark cash holdings controlling for the variation across countries, we calculate excess cash for each firm each year by comparing the amount of cash the firm holds to the amount it would be expected to hold if it were incorporated in the U.S. (see Pinkowitz and Williamson, 2001). This approach is similar to the approach pioneered by Rajan and Zingales (1998) at the industry level. DMS also use this approach for some of their regressions. Every year, regressions are run on the full panel of U.S. Compustat industrial firms to compute the coefficients in a model to determine cash holdings. Cash is defined as cash on hand plus marketable securities. ${ }^{3}$ The model is the same as in Opler et al. (1999) except that the regulation dummy and industry volatility variables are omitted. Further, while Opler et al. (1999) use market-to-book as a proxy for growth opportunities, we use sales growth. The reason for this choice is that market-to-book is negatively correlated with investor protection, so that when using a sample of firms from different countries, market-to-book becomes an inappropriate proxy for growth opportunities. The model is:

$$
\text { Cash }_{i}=\alpha_{i}+\beta_{1} \text { Size }_{i}+\beta_{2} \text { Sales growth }_{i}+\beta_{3} N W C_{i}+\beta_{4} \text { Capex }_{i}+\beta_{5} \text { Leverage }_{i}+\beta_{6} R D_{i}+
$$

\footnotetext{
${ }^{3}$ The marketable securities are defined as temporary investments in securities that can be readily converted into cash. This definition does not include cross-holdings.
} 
where Cash is the natural log of (cash/assets), Size is the natural log of real assets (deflated by the $\mathrm{CPI}$ ), Sales growth is the past year's sales growth, $N W C$ is (current assets - current liabilities cash)/assets, Capex is capital expenditures/assets, Leverage is (short-term debt + long-term debt)/assets, $R D$ is (research and development expense/sales), Cash Flow is (EBIT - interest expense - taxes - dividends)/assets, and Div is a dummy variable which equals one if the firm paid a dividend in that year and zero otherwise. When R\&D is missing, it is set to zero. Negative dividends are set to zero. Firm years with negative sales or assets are eliminated.

The above regression is estimated each year from 1988 to 1999 and the coefficients are used to determine predicted levels of cash as if the firm were a U.S. firm. Excess cash holdings are determined by subtracting the exponentiated predicted value from the actual level of cash/assets (i.e. excess $\operatorname{cash} /$ assets $=$ cash/assets $-\exp ($ predicted $\log$ cash/assets)). Table 1 shows the distribution of firm years from each country for which we can calculate excess cash holdings. In order for a country year to be included in our sample, countries are required to have at least five firms for which we can obtain excess cash data.

\section{The cross-country determinants of liquid asset holdings}

From Section 2, we expect that liquid asset holdings are positively correlated with economic development and uncertainty, and negatively correlated with expected inflation, financial development, and the quality of institutions. To test these hypotheses, we compute the difference between a firm's liquid asset holdings and its benchmark holdings and call that difference the firm's excess cash for simplicity. This allows us to compare cash holdings relative to what they would be if the quality of institutions, financial development, and economic development were all high. We then estimate regressions where the dependent variable is excess cash and the independent variables are country characteristics. 
As shown in Table 1, there is wide variation in the number of firms in our sample across countries. If we regress excess cash on country characteristics using all firms in our sample, our results would be driven by the few countries that have most of the firms. To avoid this, we estimate the relation between excess cash and country characteristics using one observation per country per year. We choose the representative level of excess cash for a country year as being equal to the amount held by the firm with the median amount of excess cash from all firms in that country for that year. With this approach, no country dominates the results and our results do not have a misleading statistical significance driven by countries with large numbers of firms. Summary statistics for our full panel of data are shown in Table 2.

The average level of excess cash across countries varies from $-1 \%$ in Peru and New Zealand to $14 \%$ in Japan. The average of excess cash is positive for all countries but two. Excess cash is positive for 366 country years out of 401 . The median excess cash is positive for all countries but two and the average of country medians is positive. There are also differences in the quality of institutions measured by corruption, political concentration, political risk, rule of law, and risk of expropriation. Western European countries, the U.S., and Canada have the highest quality of institutions with perfect or close to perfect scores in the various measures. For our measures of the quality of institutions, the countries with poorer institutions are generally located in Asia and South America. The variation in financial development is a function of the measure used. Measured by activity proxied by turnover, South Korea has the highest activity while Chile is the most inactive. We will also use the ratio of bond and stock market capitalization to GDP. This ratio is highest for Hong Kong and lowest for Mexico. Switzerland has the highest GDP per capita and India has the lowest.

Our dataset is such that we could estimate the relation between excess cash and country characteristics using pooled time-series regressions. The problem with this approach is that it would overstate the significance of the estimates, since the observations in one year are unlikely 
to be independent of the observations in a contiguous year. Fama and French (1998) recommend the methodology of Fama-McBeth (1973) to address this issue. In contrast to the earlier research investigating implications of the quality of institutions, we can implement this method because we have 12 years of data available. Hence, the regression coefficients in Table 3 represent the time-series average of the annual regression coefficients. The t-statistics are computed using the standard error of the time-series of regression coefficients. We also estimate, but do not report, pooled time-series regressions using the full panel. Our conclusions are not sensitive to the regression technique used.

Propositions 1-3 from our model indicate that excess cash in a country should fall with the quality of institutions and the degree of financial development, and increase with economic development. Table 3 tests these three hypotheses using Fama-MacBeth regressions of excess cash on indices of the quality of institutions, a proxy for financial development, and an index of economic development, GDP per capita. The measures of the quality of institutions are the indices of political risk constructed by ICRG, political constraints, corruption, rule of law, expropriation risk, and anti-director rights. Four of these indices (the country rating, the index of political constraint, the corruption index, the index for the rule of law) change over time, but the other two (expropriation risk and anti-director rights) do not. We use stock market turnover to GDP as the measure of financial development in Panels A and B and capital market capitalization to GDP in Panels C and D. The natural logarithm of GDP per capita is used as the proxy for economic development. Additionally, we use inflation as a proxy for the cost of holding liquid assets and we use volatility of the stock market as a proxy for uncertainty.

Turnover, used as a proxy for financial development, has a significant negative coefficient in all regressions in Panels A and B. This result is consistent with Proposition 2. However, in Panels $\mathrm{C}$ and $\mathrm{D}$, we use the combined capitalization of the bond and stock markets divided by GDP as a proxy for financial development instead. The coefficient on that variable is always 
significantly positive, which is inconsistent with Proposition 2. These results have one of two interpretations. It could be that stock market activity measures financial development better than stock market capitalization. Alternatively, it could be that there is no reliable relation between financial development and cash holdings. Earlier studies which find a significant coefficient on turnover but not on stock market capitalization (see, for instance, Demirgüc-Kunt and Maksimovic, 1998) lean towards the former view. The log of GDP per capita is used as a proxy for economic development. The coefficient on this variable is always positive as predicted by Proposition 3. The coefficient on inflation is negative but not always significant. The coefficient on stock market volatility is positive and always significant. Proposition 1 states that cash holdings should be lower in countries with institutions of higher quality. Since all of the indices we use are constructed so that a higher number means better institutions, we expect a negative sign on the variables. Panel A reports the coefficients on those measures of the quality of institutions for which we have yearly data. In each case, the coefficient on the index of the quality of institutions is negative and significant as predicted.

The model in Section 2 focuses on the extraction of private benefits by large shareholders and views holding liquid assets as facilitating the extraction of private benefits. The evidence is consistent with the model, but an alternative explanation should be examined. It is well-known that ownership is more concentrated in countries with poorer institutions. If ownership is more concentrated, controlling shareholders have to bear more diversifiable risk. They might therefore want the firm to hold more cash as a way of reducing the firm's risk. In this case, greater liquid asset holdings would still be a benefit to the controlling shareholder, but a benefit of a different sort since no tunneling would take place. We examine this possibility by estimating equation (6) which includes the measure of ownership concentration in the firm's country discussed earlier. Though the coefficient on ownership concentration is positive as predicted, it is not significant. The result suggests that controlling shareholders prefer cash holdings because it allows them to 
expropriate wealth from minority shareholders rather than because it reduces the risk of the firm. A more direct test of this would be to use ownership at the firm level. Requiring reliable ownership information would reduce our sample substantially. Kalcheva and Lins (2003) find that there is a positive relation between cash holdings and control rights held by the large shareholder, suggesting that a more direct investigation of the risk aversion hypothesis is warranted. $^{4}$

Panel B of Table 3 uses averages over the sample period of the measures for the quality of institutions. The literature averages the institution quality indices, perhaps because of a belief that yearly measures are noisy. We find that the coefficients are more significant when we use averages and that the regressions have slightly higher explanatory power. However, the inferences do not change. Regression (5) uses the anti-director index of LLSV1. The anti-director index has a negative coefficient, but it is not significant. This finding is not consistent with DMS. The coefficient on the anti-director rights index is quite sensitive to the control variables. It becomes significantly negative if we use total market capitalization as our proxy for financial development and also if we do not include GDP per capita as an explanatory variable. In general, if we do not include GDP per capita, our institution quality variables switch signs, so that countries with better institutions have more cash. This is because countries with better institutions have higher GDP per capita. However, with the anti-director index, this does not happen because the index is negatively correlated with GDP per capita. Hence, the omitted variable bias makes the coefficient more significant in this case, so that when we do not control for GDP per capita and use a pooled regression, we obtain the same result as DMS. Regression (6) uses the expropriation risk index of LLSV1. As expected it has a significant negative coefficient. Finally, regression (7) in Panel B shows that firms in countries with a civil law legal system hold more

\footnotetext{
${ }^{4}$ The paper by Kalcheva and Lins (2003) is contemporaneous to this paper. They investigate the relation between cash, firm value, and ownership for 1996. They use the anti-director index as their measure of shareholder protection. In their paper, using this index has no impact on the adjusted R-square.
} 
liquid assets. Overall, the regressions support the idea that in countries with institutions of poorer quality, firms hold greater levels of cash. The results in Panels A and B of Table 3 seem to provide strong support for Proposition 1.

We investigate the robustness of the results using other measures of the quality of institutions and of financial development. In regressions not reported in a table, we find that other country indices, other measures of political constraint, and creditor rights all have coefficients consistent with the regressions reported in Table 3. We then examine further the robustness of the result for financial development. We use other proxies for financial development, such as stock market capitalization to GDP, bond market capitalization to GDP, and total stock value traded to GDP. We find that the coefficient on financial market development is often significantly positive with the other measures. In Panels $\mathrm{C}$ and $\mathrm{D}$ of Table 3, we report regressions similar to those of Panels A and B, but use the sum of the capitalization of the stock market and the bond market normalized by GDP as our proxy for financial development. This measure is available only from 1989 through 1999. The coefficient on this proxy for financial development is always significantly positive, which is inconsistent with the tradeoff theory. However, the coefficients on the institution quality measures are always significantly negative regardless of which financial development variable we use. The bottom line of the investigation is that the relation between the quality of institutions and liquid asset holdings is robust, in that it does not depend on which proxy we use for financial development or whether we even use a proxy.

We examine whether the variation across years of the financial development proxies is responsible for the lack of reliability of our inferences about financial development, but that is not the case. The same conclusions hold if we use the level of financial development at one point in time. Finally, we add to regression (8) a quality of institutions variable to examine the effect of simultaneously controlling for ownership structure. When we do that, the quality of institutions variable still has a negative and significant coefficient irrespective of which variable we use. We 
also estimate a regression where we use all the proxies for the quality of institutions. With this regression, it is not surprising that some of the measures of the quality of institutions are insignificant since they are all highly correlated. The indices of corruption and law and order have negative significant coefficients. In virtually all the regressions we estimate, GDP per capita and stock market volatility have significant positive coefficients, while inflation has negative coefficients. The conclusion from all these alternate regressions is that the relation between measures of the quality of institutions and liquid asset holdings is extremely robust.

\section{The market value of cash holdings}

In the previous section, we find strong support for Propositions 1 and 3 of our model, but no reliable support for Proposition 2. These results are consistent with the tradeoff theory as well as with the agency costs theory. We therefore have to investigate Proposition 4 which has sharply different predictions depending on which one of these two theories applies. Proposition 4 predicts that, in the presence of agency costs, cash will be worth less to minority investors when the quality of institutions is lower because they expect more of the cash to be expropriated by controlling shareholders. In contrast, if the tradeoff theory holds, investors should value liquid asset holdings at roughly a dollar since if they were worth less the firm could pay out the cash it holds. Data for our firm level analysis come from the Worldscope Database. There are obvious reasons to be cautious in interpreting the results of the regressions since we are estimating a regression using data from different countries with different accounting conventions. There is no clear way to make the data across countries more comparable beyond what Worldscope already does.

To estimate the value of cash, it is necessary to have a regression model for the value of the firm and then to be able to separate cash in that regression model so that its contribution to firm value can be examined directly. Fama and French (1998) develop a valuation regression that 
performs well when subjected to a battery of tests. Pinkowitz and Williamson (2003) show how to use that valuation regression to estimate the value of cash in the U.S. In this regression model, cash enters in a straightforward way without altering any of the properties of the regression. This makes it straightforward to estimate the contribution of cash to the value of the firm. The basic regression specification is:

$$
\begin{aligned}
& M_{i, t}=\alpha+\beta_{1} E_{i, t}+\beta_{2} d E_{i, t}+\beta_{3} d E_{i, t+1}+\beta_{4} d N A_{i, t}+\beta_{5} d N A_{i, t+1}+ \\
& \beta_{6} R D_{i, t}+\beta_{7} d R D_{i, t}+\beta_{8} d R D_{i, t+1}+\beta_{9} I_{i, t}+\beta_{10} d I_{i, t}+\beta_{11} d I_{i, t+1}+\beta_{12} D_{i, t}+ \\
& \beta_{13} d D_{i, t}+\beta_{14} d D_{i, t+1}+\beta_{15} d M_{i, t+1}+\beta_{16} C_{i, t}+\varepsilon_{i, t}
\end{aligned}
$$

where $M$ is the market value of equity calculated at fiscal year end; $E$ is earnings before extraordinary items plus interest, deferred tax credits, and investment tax credits; $N A$ is net assets, defined as total assets less cash; $R D$ is research and development expense; $I$ is interest expense; $D$ is dividends defined as common dividends paid; and $C$ is cash and cash equivalents. When $\mathrm{R} \& \mathrm{D}$ is missing, we set it equal to zero.

To control for heteroscedasticity, all variables are deflated by total assets. Regarding notation, in equation (8) we refer to $\mathrm{X}_{\mathrm{t}}$ as the level of variable $\mathrm{X}$ in year $\mathrm{t}$ divided by the level of assets in year $t$. We use $\mathrm{dX}_{\mathrm{t}}$ to indicate the change in the level of $\mathrm{X}$ from year $\mathrm{t}-1$ to year $\mathrm{t}$, divided by the book value of assets in year $t\left(\left(\mathrm{X}_{\mathrm{t}-1}-\mathrm{X}_{\mathrm{t}}\right) /\right.$ Assets $\left._{\mathrm{t}}\right)$. Similarly, $\mathrm{dX}_{\mathrm{t}+1}$ indicates the change in the level of $\mathrm{X}$ from year $\mathrm{t}$ to year $\mathrm{t}+1$, divided by the book value of assets in year $\mathrm{t}\left(\left(\mathrm{X}_{\mathrm{t}+1}\right.\right.$ $\left.\mathrm{X}_{\mathrm{t}}\right) /$ Assets $_{\mathrm{t}}$ ). We follow Fama and French (1998) and estimate equation (8) using Fama-MacBeth regressions. Because we use leads and lags, the t-statistics are somewhat overstated as discussed in Fama and French (1998). To reduce the effect of outliers, we trim our sample at the $1 \%$ tails of each variable. Our final sample contains 75,232 firm years representing 13,018 unique firms. 
To examine Proposition 4, we need to segment the firms on the basis of the quality of institutions and financial development. Each year, we separate countries into high and low classifications based on whether they are above or below the median of the studied variable. Once the countries are assigned as high or low, all firms within each country are assigned the same classification as the country itself.

As an example, when we examine the political risk index, ICRGP, firms are classified as firms coming from a country with low political risk, i.e., high quality of institutions, if in a particular year they are in a country which has an ICRGP index higher than the median ICRGP index of all the countries that year for which we have data. Thus, while the number of countries classified as high or low quality of institutions is equal each year, the number of firms classified as high or low quality of institutions can vary greatly. Countries (and hence firms) are reclassified each year to account for the possibility that the quality of institutions and financial development in a country may change through time, either absolutely or relative to other countries.

An alternative approach is to estimate the value of cash using all observations but allowing for firm valuation and cash valuation to depend on the quality of institutions. From our classification scheme, we create two dummy variables we call Hi and Low. The variable Hi (Low) equals one if the firm is in a country which has high (low) quality institutions, and zero otherwise. The coefficients of interest in our regression tests are those on the interaction variables between the Hi and Low dummy variables and our continuous variable $\mathrm{C}$, representing cash holdings. In equation (9), these coefficients are shown as $\beta_{16}$ and $\beta_{17}$. Because the dependent variable is essentially the market to book ratio of the firm's equity, $\beta_{16}\left(\beta_{17}\right)$ represents the market to book value of cash holdings to minority shareholders for firms in countries with high (low) quality institutions. When cash is carried on the books dollar for dollar, the coefficient 
represents the market value of the marginal dollar of cash holdings for the firm. ${ }^{5}$ To account for the fact that market to book values are likely to be affected directly by institution quality, the regression also includes separate intercepts for high and low quality countries:

$$
\begin{aligned}
& M_{i, t}=\alpha+\alpha_{1} H i+\beta_{1} E_{i, t}+\beta_{2} d E_{i, t}+\beta_{3} d E_{i, t+1}+\beta_{4} d N A_{i, t}+\beta_{5} d N A_{i, t+1}+ \\
& \beta_{6} R D_{i, t}+\beta_{7} d R D_{i, t}+\beta_{8} d R D_{i, t+1}+\beta_{9} I_{i, t}+\beta_{10} d I_{i, t}+\beta_{11} d I_{i, t+1}+\beta_{12} D_{i, t}+ \\
& \beta_{13} d D_{i, t}+\beta_{14} d D_{i, t+1}+\beta_{15} d M_{i, t+1}+\beta_{16}\left(H i_{i, t} \times C_{i, t}\right)+\beta_{17}\left(\text { Low }_{i, t} \times C_{i, t}\right)+\varepsilon_{i, t}
\end{aligned}
$$

Because we estimate the regression using firms in both high and low ranked countries simultaneously, we refer to these tests as the joint regressions.

Table 4 reports the separate regressions using ICRGP. The third column reports the p-value for the difference in the coefficients of the two separate regressions. Remember that a high value for the ICRGP index means low political risk. The coefficient on cash is 1.04 for high ICRGP index countries and 0.58 for the other countries. Both coefficients are significant and are significantly different from each other at better than the $5 \%$ level. When we investigate the other coefficients, we find that the coefficient differences that are significant indicate that determinants of value have more of an impact on value in countries with better institutions. This is consistent with LLSV2. In particular, there is evidence in the regression that shareholders benefit more from earnings, tangible investment, and R\&D investment in countries with better institutions.

We estimate joint and separate regressions using each of our institution quality variables. For brevity and ease of presentation, in Table 5 we only report the coefficients and standard errors on cash holdings. ${ }^{6}$ With our methodology and sample, we are able to estimate 11 cross-sectional regressions for all the quality of institutions proxies as well as GDP per capita. Due to data

\footnotetext{
${ }^{5}$ In a number of countries, liquid assets are carried at lower of market or cost. In these countries, the coefficient on cash holdings has an upward bias.

${ }^{6}$ Full results of the estimation are available upon request from the authors.
} 
limitations, we have only 10 cross-sections to test for the relation between the value of cash and bond market capitalization or total capital market capitalization.

The first six regressions examine the impact of the quality of institutions on the value of cash holdings. Countries with poorer quality institutions have a lower market value of cash, which is consistent with the agency costs theory. The results are quite robust and consistent across each of the different proxies for the quality of institutions. In countries with institutions of high quality, the estimates show that a marginal dollar of cash is valued from $\$ 1.07$ to $\$ 1.18$ with a standard error of around seven to nine cents. Hence, it appears that in countries where the risk of expropriation from controlling shareholders is low, minority shareholders price cash holdings at their face value. However, the results for countries with higher risk of expropriation indicate a substantial discount placed on the value of liquid assets. The estimates range from $\$ 0.23$ to $\$ 0.65$ depending on the proxy used, with standard errors around eight to sixteen cents. In all six specifications, the value assigned to cash holdings between high and low quality of institutions countries is significantly different at the $1 \%$ level. Minority investors value cash holdings less in countries where the incidence of corruption and/or the probability of expropriation are higher. The impact of the quality of institutions on the intercept of the joint regressions is almost never significant, but it is positive and significant for the anti-director index.

We saw that cash holdings are related to economic and financial development. In equation (6), after controlling for cash flow, there is no relation between the discount for cash and either economic or financial development. However, the quality of institutions is positively correlated with financial development and economic development. Because of this correlation, we would expect cash to be worth more in countries with higher financial and economic development. Alternatively, however, it could be that firms in countries with lower financial and economic development are somehow constrained in their cash holdings, so that they hold less cash than would be optimal for them. If that were the case, cash should be more valuable in countries where 
such constraints are important, which would presumably be the countries with low financial and economic development. We therefore consider how the value of cash is correlated with financial and economic development.

We use four variables as proxies for the degree of financial development: stock market turnover, stock market capitalization, corporate bond market capitalization, and total market (stock plus bond) capitalization. For normalization purposes, all of the variables are deflated by the annual GDP of the country. We find that in countries where stock markets are active, cash is valued at $\$ 1.25$ with a standard error of $\$ 0.13$. However, in countries with low market turnover, the estimate is only $\$ 0.62$ and the difference between the two coefficients is significant at the one percent level. We also examine three variables which look at the size of the capital markets within a country. In countries with greater stock market capitalization, cash appears to be worth above face value; however, in countries with smaller capitalized equity markets, cash is valued at a deep discount. Our estimate indicates that the marginal dollar of liquid assets is valued at only \$0.17. The difference between the two is highly significant. When we measure financial development by the size of the corporate bond market, we find no statistical difference among high and low development countries. Even in economic terms, the difference appears to be small. In countries with developed bond markets the value of a dollar is $\$ 1.09$ while the estimate for lesser developed countries is $\$ 0.62$. One possibility for the discrepancy between the results segmenting firms by bond market capitalization rather than stock market capitalization is the difference in data availability. As mentioned previously, we only have bond capitalizations for 10 years as opposed to 11 years for stock capitalizations. To determine whether this discrepancy is affecting the results, for those 10 years, we examine a measure of total market capitalization which is defined as the sum of the stock and bond capitalizations normalized by GDP. The results are similar to those for bond capitalization alone. Cash holdings are more valuable in countries with better developed capital markets. In addition, we reexamine stock capitalization 
using only 10 cross-sections and find that our estimates are very similar to those obtained using the full sample. Overall, it appears that cash holdings are more valuable in countries with a greater degree of financial development. The fact that we do not find a difference when financial development is measured using bond market capitalization suggests that there may be some key difference between equity and debt capital markets. The last row of Table 5 shows that cash holdings are valued at face value in highly developed countries but are worth only $\$ 0.56$ in lesser developed ones. It follows from this that cash is valued less in countries with poor financial and economic development. Most likely, this is because in these countries cash is more likely to be expropriated from minority shareholders. There is no evidence that firms are constrained from having too little cash in these countries.

While the joint regressions allow us to use all the data and thus provide for more efficient estimates, the efficiency comes at a price. Implicitly, the joint regressions constrain all of the coefficients on the control variables to be equal for both high and low ranked countries. The separate regressions do not impose this constraint. We reproduce estimates of the cash coefficients for the separate regressions in the third and fourth columns of Table $5 .{ }^{7}$ The estimates of the value assigned to a marginal dollar of cash are surprisingly similar across the methods. The estimates for firms from high institution quality or high development countries are basically identical to those estimated in the joint regressions. For the firms from low institution quality countries, the separate regression coefficients tend to be even lower than their jointly estimated counterparts. This same result obtains in the GDP regression, but not in the financial development regressions where bond market capitalization and total capitalization are not significantly different.

We investigated an alternative specification of the regressions reported in Tables 4 and 5. In that specification, we used the original equation estimated by Fama and French (1998), but

\footnotetext{
${ }^{7}$ For brevity we report only the coefficients on the cash variable $\left(\beta_{16}\right)$, but the full results of the estimation are available upon request from the authors.
} 
divided the change of net assets into a cash component and a non-cash component. We find results consistent with the regressions reproduced here, namely a change in cash is worth less in countries with poor investor protection.

In summary, the results in this section show that minority investors assign a lower value to cash held by firms in countries with poorer quality institutions, those with less developed equity markets, and countries with lesser economic development. The results persist in different estimation specifications as well as across a robust set of proxies for institutional quality. Overall, the results are consistent with the hypothesis that minority investors put a lower value on cash when he/she feels there may be a high probability of being expropriated.

\section{Conclusion}

In this paper, we examine two theories of the determinants of liquid asset holdings of firms across countries. One theory, the tradeoff theory, assumes that managers maximize firm value. The other theory, the agency theory, assumes that large shareholders in countries with poor investor protection have incentives to make decisions that enable them to appropriate more private benefits from control. Because it is easier to expropriate cash than fixed assets, firms in countries with poor investor protection are predicted to hold more cash with that theory. We find that the empirical evidence on the determinants of liquid asset holdings is largely consistent with both theories. We then turn to an examination of the relation between the liquid assets held by a firm and the value of that firm. The liquid assets held by firms in countries with poor institutions contribute substantially less to the value of minority shares than the liquid assets held by firms in countries with better institutions. This evidence shows that agency costs play an important role in how minority investors value cash held by corporations. 


\section{References}

Acemoglu, D., S. Johnson, and J. A. Robinson, 2001, The colonial origins of comparative development: An empirical investigation, American Economic Review 91, 1369-1401.

Acemoglu, D., S. Johnson, J. A. Robinson, and Y. Thaicharoen, 2003, Institutional causes, macroeconomic symptoms: Volatility, crises, and growth, Journal of Monetary Economics.

Almeida, H., M. Campello, and M. Weisbach, 2003, The cash flow sensitivity of cash, Journal of Finance, forthcoming.

Beck, T., Demirgüç-Kunt A., Levine, R., 1999, A new database on financial development and structure, working paper, University of Minnesota, Minneapolis.

Booth, L., V. Aivazian, A. Demirgüc-Kunt, and V. Maksimovic, 2001, Capital structures in developing countries, Journal of Finance, 87-129.

Claessens, S., and Laeven, L., 2003, Financial development, property rights, and growth, Journal of Finance, forthcoming.

Dalquist, M., L Pinkowitz, R. M. Stulz, and R. Williamson, 2003, Corporate governance and the home bias, Journal of Financial and Quantitative Analysis, 87 - 110.

Demirgüc-Kunt, A. and V. Maksimovic, 1998, Law, Finance, and Firm Growth, Journal of Finance, Vol. 53, pp. 2107-2137.

Dittmar, A., Mahrt-Smith, J., and H. Servaes, 2003, International Corporate Governance and Corporate Cash Holdings, Journal of Financial and Quantitative Analysis, Vol 38.

Easterly, W., 2001, The elusive quest for growth: Economists' adventures and misadventures in the tropics, MIT Press, Cambridge, MA.

Fama, E. F. and K. R. French, 1998, Taxes, financing decisions, and firm value, Journal of Finance 53, 819-843.

Fama, E. F., and J. D. MacBeth, 1973, Risk, return, and equilibrium: Empirical tests, Journal of Political Economy 81, 607-636. 
Jensen, M., 1986, Agency Costs of Free Cash Flow, Corporate Finance and Takeovers, American Economic Review, Vol. 76, pp. 323-339.

Hart, O., and J. Moore, 1994, A theory of debt based on the inalienability of human capital, Quarterly Journal of Economics 109, 841-879.

Henisz, W. J., 2000, The institutional environment for economic growth, Economics and Politics $12,1-31$.

Johnson, S., R. La Porta, F. Lopez-de-Silanes, and A. Shleifer, 2000, Tunneling, American Economic Review 90, 22-27.

Kalcheva, I, and K. Lins, 2003, International evidence on cash holdings and expected managerial agency problems, unpublished working paper, University of Utah, Salt Lake City, Utah.

Kaufman, D., and S.-J. Wei, 1999, Does corruption grease the wheels of commerce?, unpublished working paper, World Bank, Washington, D.C.

Keynes, J.M., 1934, The General Theory of Employment, Interest and Money, in the 1973 edition of the Collected Writings of John Maynard Keynes, Vol. 7. edited by Donald Moggridge, London: Macmillan for the Royal Economic Society.

La Porta, R., F. Lopez-de-Silanes, and A. Shleifer, 1999, Corporate ownership around the world, Journal of Finance 54, 471-517.

La Porta, R., F. Lopez-de-Silanes, A. Shleifer, and R. Vishny, 1998, Law and finance, Journal of Political Economy 106, 1113-1155.

La Porta, R., F. Lopez-de-Silanes, A. Shleifer, and R. Vishny, 2000, Investor protection and corporate governance, Journal of Financial Economics 58, 3-27.

La Porta, R., F. Lopez-de-Silanes, A. Shleifer, and R. Vishny, 2002, Investor protection and corporate valuation, Journal of Finance 57, 1147-1170.

Levine, R., 1997, Financial development and economic growth: View and agenda, Journal of Economic Literature 35, 688-726.

Love, I., 2000, Financial development and financing constraints: International evidence from the structural investment model, working paper, World Bank, Washington, DC. 
Mulligan, C.B., 1997, Scale economies, the value of time, and the demand for money: Longitudinal evidence from firms, Journal of Political Economy 105, 1061-1079.

Myers, S. C., and R. G. Rajan, 1998, The paradox of liquidity, Quarterly Journal of Economics $108,733-771$.

Opler, T., L. Pinkowitz, R. Stulz, and R. Williamson, 1999, The determinants and implications of corporate cash holdings, Journal of Financial Economics 52, 3-46.

Pinkowitz, L., and R. Williamson, 2001, Bank power and cash holdings: Evidence from Japan, Review of Financial Studies 14, 1059-1082.

Pinkowitz, L. and R. Williamson, 2003, What is a dollar worth? The market value of cash holdings, Working paper, Georgetown University.

Rajan, R. G., and L. Zingales, 1998, Financial dependence and growth, AmericanEconomic Review 88, 559-586.

Shleifer, A., Vishny, R. W., 1993, Corruption, Quarterly Journal of Economics 108, 599-618.

Shleifer, A., and D. Wolfenzon, 2003, Investor protection and equity markets, Journal of Financial Economics 66, 3-27.

Stulz, R. M. and R. Williamson, 2003, Culture, openness and finance, Journal of Financial Economics, forthcoming. 
Table 1 Worldscope Sample

Firm years are based on number of firms for which excess cash can be computed.

\begin{tabular}{|c|c|c|c|c|c|}
\hline Country & Years & $\begin{array}{l}\text { Mean Firms } \\
\text { per year }\end{array}$ & $\begin{array}{c}\text { Median Firms } \\
\text { per year }\end{array}$ & $\begin{array}{c}\text { Minimum } \\
\text { Firms per year }\end{array}$ & $\begin{array}{c}\text { Maximum } \\
\text { Firms per year }\end{array}$ \\
\hline Argentina & 1988-1999 & 22.33 & 26 & 5 & 38 \\
\hline Australia & 1988-1999 & 174.25 & 178 & 123 & 206 \\
\hline Austria & 1988-1999 & 52.08 & 53 & 30 & 65 \\
\hline Belgium & 1988-1999 & 68.833 & 71.5 & 51 & 72 \\
\hline Brazil & 1988-1999 & 69.83 & 76.5 & 13 & 119 \\
\hline Canada & 1988-1999 & 393.00 & 402.5 & 332 & 428 \\
\hline Chile & 1988-1999 & 44.75 & 47 & 20 & 71 \\
\hline Denmark & 1988-1999 & 112.00 & 123.5 & 52 & 132 \\
\hline Finland & 1988-1999 & 96.25 & 96.25 & 75 & 109 \\
\hline France & 1988-1999 & 406.25 & 419.5 & 308 & 476 \\
\hline Germany & 1988-1999 & 401.08 & 416 & 295 & 442 \\
\hline Greece & 1993-1998 & 8.67 & 9.5 & 5 & 11 \\
\hline Hong Kong & 1988-1999 & 129.25 & 95.5 & 49 & 274 \\
\hline India & 1990-1999 & 155.38 & 166 & 16 & 296 \\
\hline Ireland & 1988-1999 & 43.50 & 46 & 27 & 49 \\
\hline Italy & 1988-1999 & 137.00 & 137.5 & 65 & 162 \\
\hline Japan & 1988-1999 & 646.58 & 453.5 & 105 & 1232 \\
\hline Korea (South) & 1988-1999 & 139.67 & 105.5 & 29 & 245 \\
\hline Malaysia & 1988-1999 & 174.67 & 176 & 53 & 314 \\
\hline Mexico & 1988-1999 & 48.92 & 53.5 & 23 & 70 \\
\hline Netherlands & 1988-1999 & 159.75 & 165.5 & 122 & 184 \\
\hline New Zealand & 1988-1999 & 32.67 & 30 & 20 & 46 \\
\hline Norway & 1988-1999 & 90.58 & 91 & 73 & 101 \\
\hline Peru & $1992-1998$ & 18.71 & 19 & 6 & 27 \\
\hline Philippines & 1988-1999 & 33.64 & 34 & 6 & 65 \\
\hline Portugal & 1988-1999 & 28.50 & 28 & 9 & 52 \\
\hline Singapore & 1988-1999 & 99.33 & 92.5 & 37 & 171 \\
\hline South Africa & 1988-1999 & 124.75 & 135.5 & 96 & 146 \\
\hline Spain & 1988-1999 & 97.33 & 108.5 & 54 & 116 \\
\hline Sweden & 1988-1999 & 142.75 & 151.5 & 101 & 159 \\
\hline Switzerland & 1988-1999 & 117.25 & 127.5 & 75 & 139 \\
\hline Thailand & 1990-1999 & 128.82 & 172 & 5 & 211 \\
\hline Turkey & 1990-1999 & 22.30 & 22 & 11 & 36 \\
\hline United Kingdom & 1988-1999 & 1177.50 & 1220 & 849 & 1339 \\
\hline United States & 1988-1999 & 2264.92 & 2507.5 & 386 & 2879 \\
\hline
\end{tabular}




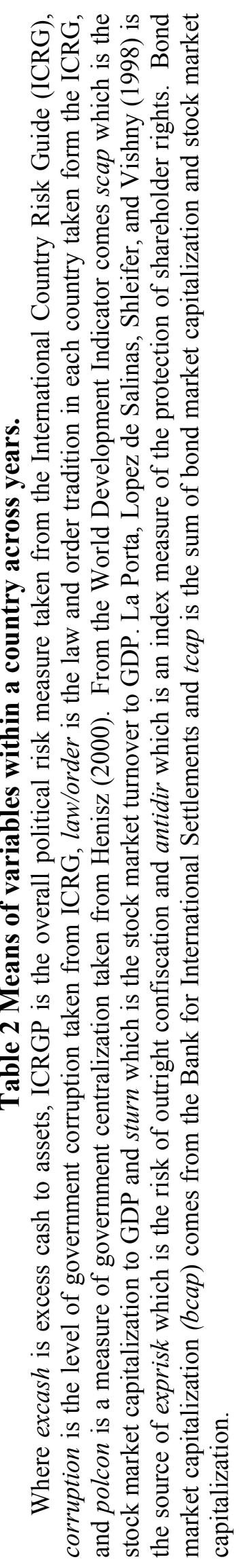




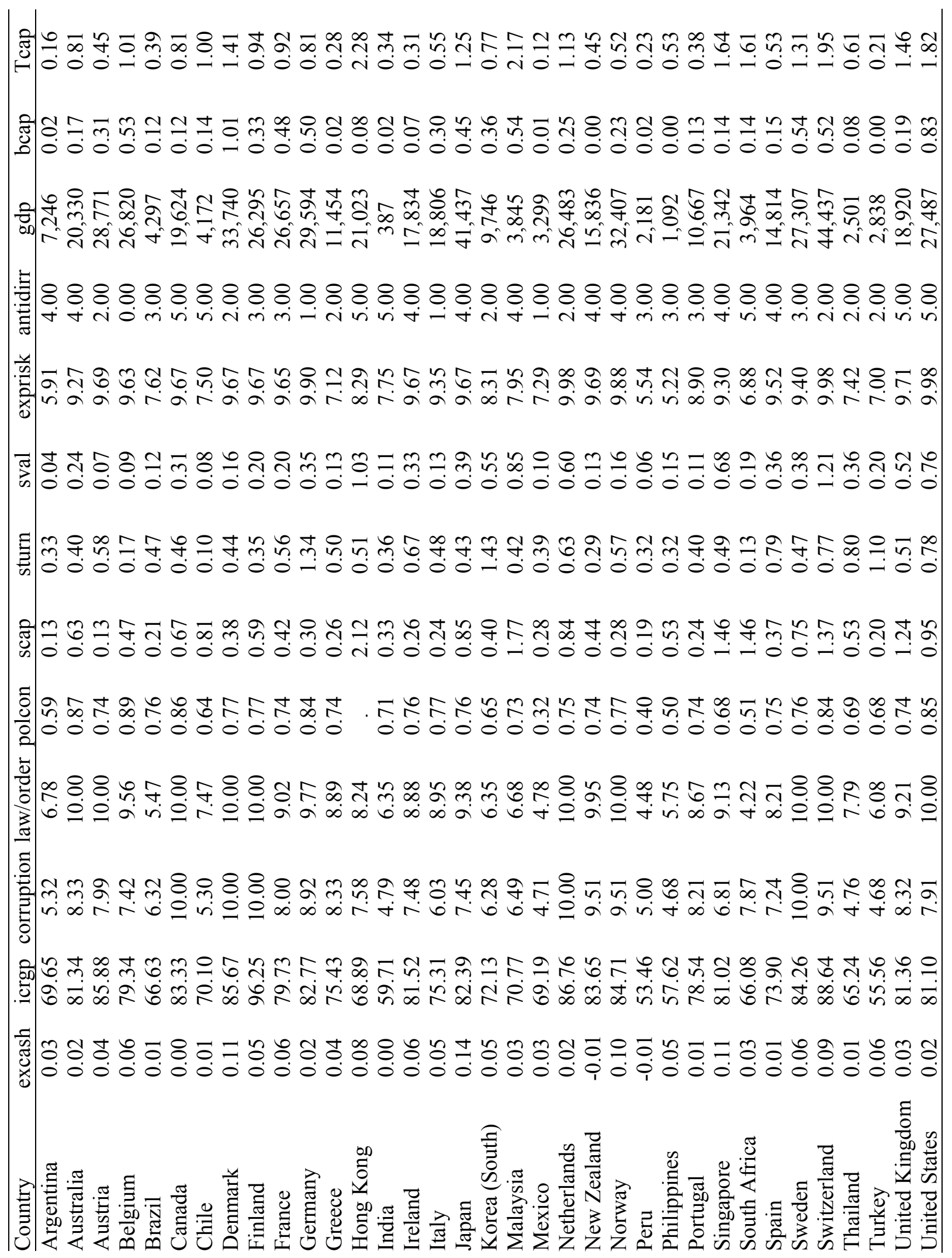


Table 3 Regressions of excess cash holdings

Regressions are run using the method of Fama and MacBeth (1973) where cross-sectional regressions are run each year and the time series of coefficients are used to make inferences. $\mathrm{N}$ is the number of cross-sectional regressions and the adjusted $\mathrm{R}^{2}$ is the mean of the adjusted $\mathrm{R}^{2} \mathrm{~s}$ of the cross-section regressions. Values in parentheses are t-values.

Panel A. Institution quality variables measured annually from 1988 through 1999.

\begin{tabular}{|c|c|c|c|c|c|c|}
\hline & (1) & (2) & (3) & (4) & (5) & (6) \\
\hline Intercept & $\begin{array}{l}-0.206 \\
(-6.70)\end{array}$ & $\begin{array}{l}-0.207 \\
(-7.32)\end{array}$ & $\begin{array}{l}-0.217 \\
(-6.79)\end{array}$ & $\begin{array}{l}-0.224 \\
(-7.94)\end{array}$ & $\begin{array}{l}-0.275 \\
(-7.73)\end{array}$ & $\begin{array}{l}-0.213 \\
(-5.95)\end{array}$ \\
\hline Inflation & $\begin{array}{l}-0.026 \\
(-0.90)\end{array}$ & $\begin{array}{l}-0.038 \\
(-1.40)\end{array}$ & $\begin{array}{l}-0.119 \\
(-1.48)\end{array}$ & $\begin{array}{l}-0.030 \\
(-0.99)\end{array}$ & $\begin{array}{l}-0.078 \\
(-1.62)\end{array}$ & $\begin{array}{l}-0.014 \\
(-0.45)\end{array}$ \\
\hline $\begin{array}{l}\text { Stock market } \\
\text { volatility }\end{array}$ & $\begin{array}{l}0.569 \\
(4.75)\end{array}$ & $\begin{array}{l}0.527 \\
(4.15)\end{array}$ & $\begin{array}{l}0.550 \\
(6.06)\end{array}$ & $\begin{array}{l}0.474 \\
(3.85)\end{array}$ & $\begin{array}{l}0.607 \\
(6.36)\end{array}$ & $\begin{array}{l}0.514 \\
(3.73)\end{array}$ \\
\hline $\begin{array}{l}\text { Stock market } \\
\text { turnover to GDP }\end{array}$ & $\begin{array}{l}-0.011 \\
(-3.82)\end{array}$ & $\begin{array}{l}-0.010 \\
(-3.50)\end{array}$ & $\begin{array}{l}-0.011 \\
(-3.67)\end{array}$ & $\begin{array}{l}-0.016 \\
(-2.95)\end{array}$ & $\begin{array}{l}-0.013 \\
(-3.00)\end{array}$ & $\begin{array}{l}-0.008 \\
(-2.16)\end{array}$ \\
\hline $\begin{array}{l}\text { Log (GDP per } \\
\text { capita) }\end{array}$ & $\begin{array}{l}0.023 \\
(8.72)\end{array}$ & $\begin{array}{l}0.035 \\
(7.31)\end{array}$ & $\begin{array}{l}0.030 \\
(7.52)\end{array}$ & $\begin{array}{c}0.032 \\
(10.89)\end{array}$ & $\begin{array}{l}0.038 \\
(7.83)\end{array}$ & $\begin{array}{l}0.023 \\
(6.87)\end{array}$ \\
\hline ICRGP & & $\begin{array}{l}-0.001 \\
(-2.75)\end{array}$ & & & & \\
\hline Polcon & & & $\begin{array}{l}-0.068 \\
(-2.51)\end{array}$ & & & \\
\hline Corruption & & & & $\begin{array}{l}-0.007 \\
(-4.31)\end{array}$ & & \\
\hline Law and Order & & & & & $\begin{array}{l}-0.009 \\
(-5.34)\end{array}$ & \\
\hline $\begin{array}{l}\text { Closely Held } \\
\text { Ownership }\end{array}$ & & & & & & $\begin{array}{l}0.025 \\
(1.55)\end{array}$ \\
\hline Adjusted $\mathrm{R}^{2}$ & 0.2189 & 0.2528 & 0.2475 & 0.2575 & 0.2717 & 0.2059 \\
\hline $\mathrm{N}$ & 12 & 12 & 12 & 12 & 12 & 12 \\
\hline
\end{tabular}


Panel B. Institution quality variables averaged over 1988-1999.

\begin{tabular}{|c|c|c|c|c|c|c|c|c|}
\hline & (1) & (2) & (3) & (4) & $(5)$ & (6) & (7) & (8) \\
\hline Intercept & $\begin{array}{l}-0.158 \\
(-4.55)\end{array}$ & $\begin{array}{l}-0.155 \\
(-2.73)\end{array}$ & $\begin{array}{l}-0.216 \\
(-7.13)\end{array}$ & $\begin{array}{l}-0.269 \\
(-6.17)\end{array}$ & $\begin{array}{l}-0.206 \\
(-6.31)\end{array}$ & $\begin{array}{c}-0.206 \\
(-13.73)\end{array}$ & $\begin{array}{l}-0.196 \\
(-6.79)\end{array}$ & $\begin{array}{l}-0.212 \\
(-5.56)\end{array}$ \\
\hline Inflation & $\begin{array}{l}-0.069 \\
(-1.70)\end{array}$ & $\begin{array}{l}-0.142 \\
(-1.39)\end{array}$ & $\begin{array}{l}-0.026 \\
(-0.89)\end{array}$ & $\begin{array}{c}-0.108(- \\
1.78)\end{array}$ & $\begin{array}{l}-0.031 \\
(-0.99)\end{array}$ & $\begin{array}{l}-0.130 \\
(-1.59)\end{array}$ & $\begin{array}{l}-0.036 \\
(-1.08)\end{array}$ & $\begin{array}{l}-0.020 \\
(-0.70)\end{array}$ \\
\hline $\begin{array}{l}\text { Stock market } \\
\text { volatility }\end{array}$ & $\begin{array}{l}0.516 \\
(4.40)\end{array}$ & $\begin{array}{l}0.491 \\
(3.09)\end{array}$ & $\begin{array}{l}0.439 \\
(3.28)\end{array}$ & $\begin{array}{l}0.615 \\
(5.46)\end{array}$ & $\begin{array}{l}0.571 \\
(4.62)\end{array}$ & $\begin{array}{l}0.589 \\
(9.18)\end{array}$ & $\begin{array}{l}0.580 \\
(4.67)\end{array}$ & $\begin{array}{l}0.502 \\
(3.50)\end{array}$ \\
\hline $\begin{array}{l}\text { Stock market } \\
\text { turnover to GDP }\end{array}$ & $\begin{array}{l}-0.014 \\
(-5.16)\end{array}$ & $\begin{array}{l}-0.011 \\
(-4.05)\end{array}$ & $\begin{array}{l}-0.033 \\
(-3.78)\end{array}$ & $\begin{array}{l}-0.014 \\
(-6.47)\end{array}$ & $\begin{array}{l}-0.012 \\
(-3.53)\end{array}$ & $\begin{array}{l}-0.009 \\
(-4.52)\end{array}$ & $\begin{array}{l}-0.012 \\
(-4.13)\end{array}$ & $\begin{array}{l}-0.009 \\
(-2.98)\end{array}$ \\
\hline $\begin{array}{l}\text { Log (GDP per } \\
\text { capita) }\end{array}$ & $\begin{array}{c}0.036 \\
(12.40)\end{array}$ & $\begin{array}{l}0.030 \\
(4.05)\end{array}$ & $\begin{array}{c}0.032 \\
(12.23)\end{array}$ & $\begin{array}{l}0.042 \\
(6.82)\end{array}$ & $\begin{array}{l}0.023 \\
(8.59)\end{array}$ & $\begin{array}{l}0.048 \\
(4.64)\end{array}$ & $\begin{array}{l}0.021 \\
(8.06)\end{array}$ & $\begin{array}{l}0.029 \\
(6.85)\end{array}$ \\
\hline ICRGP & $\begin{array}{l}-0.002 \\
(-4.11)\end{array}$ & & & & & & & \\
\hline Polcon & & $\begin{array}{l}-0.144 \\
(-2.62)\end{array}$ & & & & & & \\
\hline Corruption & & & $\begin{array}{l}-0.009 \\
(-5.28)\end{array}$ & & & & & \\
\hline Law and Order & & & & $\begin{array}{l}-0.013 \\
(-5.00)\end{array}$ & & & & \\
\hline Anti-Director Index & & & & & $\begin{array}{l}-0.001 \\
(-0.14)\end{array}$ & & & \\
\hline Expropriation Risk & & & & & & $\begin{array}{l}-0.026 \\
(-2.37)\end{array}$ & & \\
\hline Civil Law & & & & & & & $\begin{array}{l}0.011 \\
(2.67)\end{array}$ & \\
\hline $\begin{array}{l}\text { Closely Held } \\
\text { Ownership }\end{array}$ & & & & & & & & $\begin{array}{l}0.029 \\
(2.11)\end{array}$ \\
\hline Adjusted $\mathrm{R}^{2}$ & 0.2314 & 0.2786 & 0.2525 & 0.2835 & 0.1889 & 0.3204 & 0.2140 & 0.2025 \\
\hline $\mathrm{N}$ & 12 & 12 & 12 & 12 & 12 & 12 & 12 & 12 \\
\hline
\end{tabular}


Panel C. Institution quality variables measured annually from 1989 through 1999.

\begin{tabular}{lcccccc}
\hline & $(1)$ & $(2)$ & $(3)$ & $(4)$ & $(5)$ & $(6)$ \\
\hline Intercept & -0.197 & -0.188 & -0.212 & -0.209 & -0.233 & -0.1989 \\
& $(-7.10)$ & $(-8.02)$ & $(-7.41)$ & $(-8.07)$ & $(-10.48)$ & $(-6.93)$ \\
Inflation & -0.008 & -0.017 & -0.051 & -0.007 & -0.029 & -0.001 \\
& $(-0.31)$ & $(-0.73)$ & $(-0.95)$ & $(-0.26)$ & $(-0.91)$ & $(-0.03)$ \\
Stock market & 0.624 & 0.581 & 0.639 & 0.514 & 0.653 & 0.593 \\
volatility & $(6.46)$ & $(4.85)$ & $(7.21)$ & $(4.94)$ & $(6.67)$ & $(5.59)$ \\
(Stock+Bond) Market & 0.023 & 0.021 & 0.023 & 0.024 & 0.019 & 0.023 \\
Cap to GDP & $(3.92)$ & $(4.05)$ & $(4.70)$ & $(4.12)$ & $(3.99)$ & $(4.20)$ \\
Log (GDP per capita) & 0.019 & 0.026 & 0.025 & 0.026 & 0.028 & 0.019 \\
& $(7.15)$ & $(9.08)$ & $(11.36)$ & $(13.12)$ & $(12.26)$ & $(6.90)$ \\
ICRGP & & -0.001 & & & & \\
Polcon & & $(-2.18)$ & & & & \\
Corruption & & & -0.056 & & & \\
Law and Order & & & & & & \\
Closely Held & & & & & & \\
Ownership & & & & & & \\
Adjusted R & & & & & & \\
N & & & & & & \\
\hline
\end{tabular}


Panel D. Institution quality variables averaged over the sample period of 1989-1999 with financial development proxied by market capitalization over GDP.

\begin{tabular}{|c|c|c|c|c|c|c|c|c|}
\hline & (1) & (2) & (3) & (4) & (5) & (6) & (7) & (8) \\
\hline Intercept & $\begin{array}{l}-0.172 \\
(-4.90)\end{array}$ & $\begin{array}{l}-0.174 \\
(-3.03)\end{array}$ & $\begin{array}{l}-0.203 \\
(-7.20)\end{array}$ & $\begin{array}{l}-0.227 \\
(-7.39)\end{array}$ & $\begin{array}{l}-0.179 \\
(-5.82)\end{array}$ & $\begin{array}{c}-0.207 \\
(-11.24)\end{array}$ & $\begin{array}{l}-0.180 \\
(-6.70)\end{array}$ & $\begin{array}{l}-0.195 \\
(-6.80)\end{array}$ \\
\hline Inflation & $\begin{array}{l}-0.026 \\
(-0.80)\end{array}$ & $\begin{array}{l}-0.084 \\
(-0.98)\end{array}$ & $\begin{array}{l}-0.010 \\
(-0.36)\end{array}$ & $\begin{array}{l}-0.042 \\
(-1.10)\end{array}$ & $\begin{array}{l}-0.009 \\
(-0.35)\end{array}$ & $\begin{array}{l}-0.062 \\
(-1.06)\end{array}$ & $\begin{array}{l}-0.035 \\
(-099)\end{array}$ & $\begin{array}{l}-0.005 \\
(-0.18)\end{array}$ \\
\hline $\begin{array}{l}\text { Stock market } \\
\text { volatility }\end{array}$ & $\begin{array}{l}0.592 \\
(5.21)\end{array}$ & $\begin{array}{l}0.598 \\
(3.86)\end{array}$ & $\begin{array}{l}0.488 \\
(4.23)\end{array}$ & $\begin{array}{l}0.649 \\
(5.89)\end{array}$ & $\begin{array}{l}0.605 \\
(6.06)\end{array}$ & $\begin{array}{l}0.640 \\
(9.56)\end{array}$ & $\begin{array}{l}0.669 \\
(6.49)\end{array}$ & $\begin{array}{l}0.604 \\
(5.78)\end{array}$ \\
\hline $\begin{array}{l}\text { (Stock+Bond) } \\
\text { Market Cap to GDP }\end{array}$ & $\begin{array}{l}0.021 \\
(3.86)\end{array}$ & $\begin{array}{l}0.022 \\
(4.73)\end{array}$ & $\begin{array}{l}0.023 \\
(4.34)\end{array}$ & $\begin{array}{l}0.019 \\
(3.99)\end{array}$ & $\begin{array}{l}0.026 \\
(3.74)\end{array}$ & $\begin{array}{l}0.016 \\
(5.75)\end{array}$ & $\begin{array}{l}0.032 \\
(3.67)\end{array}$ & $\begin{array}{l}0.023 \\
(4.08)\end{array}$ \\
\hline $\begin{array}{l}\text { Log (GDP per } \\
\text { capita) }\end{array}$ & $\begin{array}{c}0.026 \\
(10.62)\end{array}$ & $\begin{array}{c}0.027 \\
(10.61)\end{array}$ & $\begin{array}{c}0.026 \\
(14.42)\end{array}$ & $\begin{array}{c}0.030 \\
(10.58)\end{array}$ & $\begin{array}{l}0.018 \\
(6.33)\end{array}$ & $\begin{array}{l}0.039 \\
(4.55)\end{array}$ & $\begin{array}{l}0.015 \\
(4.32)\end{array}$ & $\begin{array}{l}0.019 \\
(5.84)\end{array}$ \\
\hline IGCRP & $\begin{array}{l}-0.001 \\
(-2.29)\end{array}$ & & & & & & & \\
\hline Polcon & & $\begin{array}{l}-0.121 \\
(-2.68)\end{array}$ & & & & & & \\
\hline Corruption & & & $\begin{array}{c}-0.08 \\
(-5.56)\end{array}$ & & & & & \\
\hline Law and Order & & & & $\begin{array}{l}-0.008 \\
(-8.15)\end{array}$ & & & & \\
\hline Anti-director Rights & & & & & $\begin{array}{l}-0.003 \\
(-2.99)\end{array}$ & & & \\
\hline Expropriation Risk & & & & & & $\begin{array}{l}-0.020 \\
(-2.00)\end{array}$ & & \\
\hline Civil Law & & & & & & & $\begin{array}{l}0.023 \\
(3.41)\end{array}$ & \\
\hline $\begin{array}{l}\text { Closely Held } \\
\text { Ownership }\end{array}$ & & & & & & & & $\begin{array}{l}0.004 \\
(0.61)\end{array}$ \\
\hline Adjusted $\mathrm{R}^{2}$ & 0.3091 & 0.3614 & 0.3404 & 0.3349 & 0.2981 & 0.3666 & 0.3696 & 0.2925 \\
\hline $\mathrm{N}$ & 11 & 11 & 11 & 11 & 11 & 11 & 11 & 11 \\
\hline
\end{tabular}


Table 4. The value of cash and political risk.

Regressions are estimated using the method of Fama and MacBeth (1973). Regressions are estimated independently for each subsample and allow coefficients on control variables to vary across subsamples. $X_{t}$ is the level of variable $X$ in year $t$ divided by the level of assets in year $t . d_{t}$ is the change in the level of $X$ from year $t-1$ to year $t$ divided by total assets in year $t\left(\left(X_{t-1}-X_{t}\right) / A_{t}\right) . d X_{t+1}$ is the change in the level of $X$ from year $t+1$ to year $t$ divided by assets in year $t\left(\left(X_{t+1}-X_{t}\right) / A_{t}\right)$. $M$ is the market value of equity. $\mathrm{E}$ is earnings defined as earnings before extraordinary items + interest + deferred tax credits + investment tax credits. NA is net assets, which is defined as total assets - cash. $\mathrm{RD}$ is research and development expense. When $\mathrm{R} \& \mathrm{D}$ is missing, it is set to zero. I is interest expense. $\mathrm{D}$ is common dividends. $\mathrm{C}$ is cash and cash equivalents. The ICRGP index is high for countries with low political risk. The estimated regression is:

$$
\begin{aligned}
& M_{i, t}=\alpha+\beta_{1} E_{i, t}+\beta_{2} d E_{i, t}+\beta_{3} d E_{i, t+1}+\beta_{4} d N A_{i, t}+\beta_{5} d N A_{i, t+1}+ \\
& \beta_{6} R D_{i, t}+\beta_{7} d R D_{i, t}+\beta_{8} d R D_{i, t+1}+\beta_{9} I_{i, t}+\beta_{10} d I_{i, t}+\beta_{11} d I_{i, t+1}+\beta_{12} D_{i, t}+ \\
& \beta_{13} d D_{i, t}+\beta_{14} d D_{i, t+1}+\beta_{15} d M_{i, t+1}+\beta_{16} C_{i, t}+\varepsilon_{i, t}
\end{aligned}
$$




\begin{tabular}{|c|c|c|c|}
\hline & High ICRGP index & Low ICRGP index & $\begin{array}{c}\text { Difference between high } \\
\text { and low ICRGP index } \\
\text { (p-value) }\end{array}$ \\
\hline Intercept & $\begin{array}{l}0.461 \\
(9.10)\end{array}$ & $\begin{array}{c}0.464 \\
(8.64)\end{array}$ & 0.963 \\
\hline $\mathrm{E}_{\mathrm{t}}$ & $\begin{array}{c}3.516 \\
(13.03)\end{array}$ & $\begin{array}{l}3.722 \\
(9.56)\end{array}$ & 0.723 \\
\hline $\mathrm{dE}_{\mathrm{t}}$ & $\begin{array}{l}-0.475 \\
(-2.94)\end{array}$ & $\begin{array}{l}-0.498 \\
(-2.54)\end{array}$ & 0.904 \\
\hline $\mathrm{dE}_{\mathrm{t}+1}$ & $\begin{array}{l}1.820 \\
(8.51)\end{array}$ & $\begin{array}{l}1.199 \\
(5.70)\end{array}$ & 0.021 \\
\hline $\mathrm{dNA}_{\mathrm{t}}$ & $\begin{array}{l}0.530 \\
(4.79)\end{array}$ & $\begin{array}{l}0.230 \\
(2.43)\end{array}$ & 0.053 \\
\hline $\mathrm{dNA}_{\mathrm{t}+1}$ & $\begin{array}{l}0.295 \\
(5.18)\end{array}$ & $\begin{array}{l}0.233 \\
(2.96)\end{array}$ & 0.353 \\
\hline $\mathrm{RD}_{\mathrm{t}}$ & $\begin{array}{l}3.579 \\
(4.52)\end{array}$ & $\begin{array}{l}-0.162 \\
(-0.11)\end{array}$ & 0.045 \\
\hline $\mathrm{dRD}_{\mathrm{t}}$ & $\begin{array}{l}5.676 \\
(2.87)\end{array}$ & $\begin{array}{l}3.482 \\
(0.76)\end{array}$ & 0.600 \\
\hline $\mathrm{dRD}_{\mathrm{t}+1}$ & $\begin{array}{l}10.628 \\
(6.20)\end{array}$ & $\begin{array}{l}6.646 \\
(3.60)\end{array}$ & 0.039 \\
\hline$I_{t}$ & $\begin{array}{l}-8.620 \\
(-9.96)\end{array}$ & $\begin{array}{l}-6.835 \\
(-5.73)\end{array}$ & 0.151 \\
\hline $\mathrm{dI}_{\mathrm{t}}$ & $\begin{array}{l}0.152 \\
(0.17)\end{array}$ & $\begin{array}{l}1.173 \\
(0.89)\end{array}$ & 0.469 \\
\hline $\mathrm{dI}_{\mathrm{t}+1}$ & $\begin{array}{l}-5.847 \\
(-6.59)\end{array}$ & $\begin{array}{l}-2.068 \\
(-3.58)\end{array}$ & 0.005 \\
\hline $\mathrm{D}_{\mathrm{t}}$ & $\begin{array}{l}5.286 \\
(4.57)\end{array}$ & $\begin{array}{l}5.596 \\
(6.16)\end{array}$ & 0.804 \\
\hline $\mathrm{dD}_{\mathrm{t}}$ & $\begin{array}{l}0.518 \\
(0.73)\end{array}$ & $\begin{array}{l}-0.751 \\
(-1.13)\end{array}$ & 0.115 \\
\hline $\mathrm{dD}_{\mathrm{t}+1}$ & $\begin{array}{l}2.200 \\
(1.88)\end{array}$ & $\begin{array}{l}2.569 \\
(2.56)\end{array}$ & 0.799 \\
\hline $\mathrm{dM}_{\mathrm{t}+1}$ & $\begin{array}{l}0.093 \\
(1.75)\end{array}$ & $\begin{array}{l}-0.102 \\
(-1.50)\end{array}$ & 0.004 \\
\hline $\mathrm{C}_{\mathrm{t}}$ & $\begin{array}{c}1.042 \\
(10.57)\end{array}$ & $\begin{array}{l}0.577 \\
(3.61)\end{array}$ & 0.036 \\
\hline
\end{tabular}




\section{Table 5. The value of cash and investor protection.}

Regressions are run using the method of Fama and MacBeth (1973) where cross-sectional regressions are run each year and the time series of coefficients are used to make inferences. Each regression includes 12 cross-sections except for the bond market capitalization regression where we have 11 cross-sections. Joint regressions are estimated using the whole sample and have the same coefficients on control variables. Separate regressions are run independently for each subsample and allow coefficients on control variables to vary across subsamples. $\mathrm{X}_{\mathrm{t}}$ is the level of variable $\mathrm{X}$ in year $t$ divided by the level of assets in year $t$. $d X t_{t}$ is the change in the level of $X$ from year $t-1$ to year $t$ divided by total assets in year $t\left(\left(X_{t-1}-X_{t}\right) / A_{t}\right) \cdot d X_{t+1}$ is the change in the level of $X$ from year $t+1$ to year $t$ divided by assets in year $t\left(\left(X_{t+1}-X_{t}\right) / A_{t}\right)$. $M$ is the market value of equity. $E$ is earnings defined as earnings before extraordinary items + interest + deferred tax credits + investment tax credits. NA is net assets, which is defined as total assets - cash. RD is research and development expense. When R\&D is missing, it is set to zero. I is interest expense. $\mathrm{D}$ is common dividends. $\mathrm{C}$ is cash and cash equivalents. The ICRGP index is high for countries with low political risk. The standard errors are in parentheses. $*, * *, * * *$ indicate significant difference between the high and low coefficient at the 10,5 , and 1 percent significance levels.

Joint Regressions

$$
\begin{aligned}
& M_{i, t}=\alpha+\alpha_{1} H i+\beta_{1} E_{i, t}+\beta_{2} d E_{i, t}+\beta_{3} d E_{i, t+1}+\beta_{4} d N A_{i, t}+\beta_{5} d N A_{i, t+1}+ \\
& \beta_{6} R D_{i, t}+\beta_{7} d R D_{i, t}+\beta_{8} d R D_{i, t+1}+\beta_{9} I_{i, t}+\beta_{10} d I_{i, t}+\beta_{11} d I_{i, t+1}+\beta_{12} D_{i, t}+ \\
& \beta_{13} d D_{i, t}+\beta_{14} d D_{i, t+1}+\beta_{15} d M_{i, t+1}+\beta_{16}\left(H i_{i, t} \times C_{i, t}\right)+\beta_{17}\left(L o w_{i, t} \times C_{i, t}\right)+\varepsilon_{i, t}
\end{aligned}
$$

Separate Regressions

$$
\begin{aligned}
& M_{i, t}=\alpha+\beta_{1} E_{i, t}+\beta_{2} d E_{i, t}+\beta_{3} d E_{i, t+1}+\beta_{4} d N A_{i, t}+\beta_{5} d N A_{i, t+1}+ \\
& \beta_{6} R D_{i, t}+\beta_{7} d R D_{i, t}+\beta_{8} d R D_{i, t+1}+\beta_{9} I_{i, t}+\beta_{10} d I_{i, t}+\beta_{11} d I_{i, t+1}+\beta_{12} D_{i, t}+ \\
& \beta_{13} d D_{i, t}+\beta_{14} d D_{i, t+1}+\beta_{15} d M_{i, t+1}+\beta_{16} C_{i, t}+\varepsilon_{i, t}
\end{aligned}
$$




\begin{tabular}{ccc|cc} 
& \multicolumn{2}{c|}{ Joint Regressions } & \multicolumn{2}{c}{ Separate Regressions } \\
\hline \multirow{2}{*}{ Institution Quality } & $\begin{array}{c}\text { High Institution } \\
\text { Quality }\left(\beta_{16}\right)\end{array}$ & $\begin{array}{c}\text { Low Institution } \\
\text { Quality }\left(\beta_{17}\right)\end{array}$ & $\begin{array}{c}\text { High Institution } \\
\text { Quality }\left(\beta_{16}\right)\end{array}$ & $\begin{array}{c}\text { Low Institution } \\
\text { Quality }\left(\beta_{16}\right)\end{array}$ \\
\hline \multirow{2}{*}{ Corruption } & $1.07^{* * *}$ & 0.30 & $1.08^{* * *}$ & 0.02 \\
& $(0.072)$ & $(0.138)$ & $(0.080)$ & $(0.174)$ \\
Polcon & $1.13^{* * *}$ & 0.65 & $1.10^{* * *}$ & 0.69 \\
& $(0.094)$ & $(0.117)$ & $(0.098)$ & $(0.099)$ \\
ICRGP & $1.08^{* * *}$ & 0.59 & $1.04^{* * *}$ & 0.58 \\
\multirow{2}{*}{ Rule of law } & $(0.093)$ & $(0.156)$ & $(0.098)$ & $(0.159)$ \\
& $1.08^{* * *}$ & 0.47 & $1.05^{* * *}$ & 0.50 \\
Expropriation & $(0.070)$ & $(0.120)$ & $(0.084)$ & $(0.119)$ \\
& $1.07^{* * *}$ & 0.49 & $1.05^{* * *}$ & 0.48 \\
Anti-director rights & $(0.076)$ & $(0.093)$ & $(0.092)$ & $(0.075)$ \\
& $1.18^{* * *}$ & 0.23 & $1.10^{* * *}$ & 0.28 \\
& $(0.078)$ & $(0.080)$ & $(0.090)$ & $(0.075)$ \\
\hline
\end{tabular}

\begin{tabular}{ccc|cc}
\hline Financial Development & $\begin{array}{c}\text { High Development } \\
\left(\beta_{16}\right)\end{array}$ & $\begin{array}{c}\text { Low Development } \\
\left(\beta_{17}\right)\end{array}$ & $\begin{array}{c}\text { High Development } \\
\left(\beta_{16}\right)\end{array}$ & $\begin{array}{c}\text { Low Development } \\
\left(\beta_{16}\right)\end{array}$ \\
\hline Stock market turnover & $1.25^{* * *}$ & 0.62 & $1.19^{* * *}$ & 0.67 \\
to GDP & $(0.131)$ & $(0.082)$ & $(0.138)$ & $(0.072)$ \\
Stock Market & $1.15^{* * *}$ & 0.17 & $1.08^{* * *}$ & 0.29 \\
Capitalization to GDP & $(0.080)$ & $(0.100)$ & $(0.090)$ & $(0.096)$ \\
Bond Market & $1.09^{* * *}$ & 0.62 & 1.04 & 0.77 \\
Capitalization to GDP & $(0.126)$ & $(0.120)$ & $(0.134)$ & $(0.100)$ \\
Total Market & $1.04^{* * *}$ & 0.76 & 1.02 & 0.86 \\
Capitalization to GDP & $(0.092)$ & $(0.145)$ & $(0.100)$ & $(0.140)$ \\
\hline
\end{tabular}

Economic Development High Development Low Development High Development Low Development

\begin{tabular}{ccc|cc} 
& $\left(\beta_{16}\right)$ & $\left(\beta_{17}\right)$ & $\left(\beta_{16}\right)$ & $\left(\beta_{16}\right)$ \\
\hline \multirow{2}{*}{ GDP per capita } & $1.08^{* * *}$ & 0.56 & $1.04^{* * *}$ & 0.59 \\
& $(0.110)$ & $(0.132)$ & $(0.123)$ & $(0.101)$
\end{tabular}

